\title{
Deleterious effects of maternal ingestion of cocoa upon fetal ductus arteriosus in late pregnancy
}

\section{Paulo Zielinsky*, Felipe V. Martignoni and Izabele Vian}

Fetal Cardiology Unit, Institute of Cardiology of Rio Grande do Sul, Porto Alegre, Brazil

\section{Edited by:}

Rabia Latif, University of Dammam,

Saudi Arabia

\section{Reviewed by:}

Luigia Trabace, University of Foggia, Italy

Md Abdul Hye Khan, Medical College of Wisconsin, USA

\section{${ }^{*}$ Correspondence:}

Paulo Zielinsky, Fetal Cardiology Unit, Institute of Cardiology of Rio Grande do Sul, Princesa Isabel, 370 Santana, Porto Alegre, Rio Grande do Sul, Brazil e-mail: zielinsky.pesquisa@gmail.com
Cocoa powder has twice more antioxidants than red wine and three times more than green tea. Ten percent of its weight is made up of flavonoids. Cocoa has antioxidant and anti-inflammatory effects by downregulating cyclooxigenase-2 receptors expression in the endothelium and enhancing nitric oxide bioavailability. There are evidences that while polyphenols ingestion have cardioprotective effects in the adult, it may have deleterious effect on the fetus if ingested by the mother on the third trimester of pregnancy, causing intrauterine fetal ductus arteriosus (DA) constriction. Polyphenols present in many foods and their anti-inflammatory and antinociceptive activities have been shown to be as or more powerful than those of indomethacin. These effects are dependent on the inhibition of modulation of the arachidonic acid and the synthesis of prostaglandins, especially E-2, which is responsible for fetal DA patency. So, we hypothesized that this same mechanism is responsible for the harmful effect of polyphenol-rich foods, such as cocoa, upon the fetal DA after maternal intake of such substances in the third trimester of pregnancy, thereby rising the perspective of a note of caution for pregnant women diet.

Keywords: Cocoa, polyphenols, anti-inflammatory, antioxidant, fetal ductus arteriosus, ductal constriction, pregnancy
Cocoa powder has twice more antioxidants than red wine and three times more than green tea. Ten percent oh its weight is made up of flavonoids. Its sub-product, dark chocolate, shows in its composition $53.5 \mathrm{mg}$ of catechins in $100 \mathrm{~g}$ of chocolate, whereas milk chocolate has $15.9 \mathrm{mg} / 100 \mathrm{~g}$ (Arts et al., 1999).

Biologic activity of polyphenols is related to interference in the inflammatory cascade, with inhibition of prostaglandin synthesis and mediation of nitric oxide synthase 5. Among the discussed effects of cocoa consumption are interferences with vascular function, platelet reactivity and inflammatory processes, suggesting cardioprotective properties of some constituents (Arranz et al., 2013). However, the inflammatory background in disease development, like the starting point of pro-inflammatory cytokine release and metabolite production, is a central target for preventive actions. In line with this, we aim to discuss potential interferences of cocoa antioxidants with central anti-inflammatory mechanisms, by focusing on pathways involved in cyclooxygenase and nitric oxide responses, and its potential side effects.

Cocoa polyphenols modulate nuclear factor kappaB (NF-кB) activity, a protein complex involved in the transduction cascades that play a key role in inflammatory response and carcinogenesis (Sies et al., 2005; Romier-Crouzet et al., 2009). Cocoa polyphenols are potent inhibitors of the kinase activity of mitogen-activated kinase kinase (MEK), and this inhibition subsequently suppresses COX-2 expression in TPA induced inflammation (Heptinstall et al., 2006; Kang et al., 2008). Although, this effect was not observed with cocoa theobromine. MEK is a dual specificity protein kinase that phosphorylates the downstream target ERK on specific tyrosine and threonine residues. Because the expression of COX-2 is primarily regulated by eukaryotic transcription factors such as NF- $\kappa \mathrm{B}$ and activator protein (AP)-1, inhibition of AP-1 and/or NF- $\kappa \mathrm{B}$ might lead to the suppression of cell transformation through the blocking of COX-2 expression (Hsu et al., 2000; Lee and Lee, 2006; Kang et al., 2008). Stimulation of cells with various tumor promoters an pro-inflammatory substances results in the activation of AP- 1 and/or NF- $\kappa \mathrm{B}$ by a series of upstream kinases, including those belonging to the mitogen-activated protein (MAP) kinase family. The MAP kinases include extracellular signal-regulated protein kinase (ERK), c-Jun $N$-terminal kinase (JNK), and p38 MAP kinase.

Cocoas (-)-epicatechin and $(+)$-catechin reduce NF- $\kappa$ B capacity of binding to DNA by preventing the phosphorylation of inhibitor $\kappa$ B (ІкB) (Selmi et al., 2006). In a complementary study, Zhang etal. (2006) investigated the effects of procyanidins on COX2 expression on THP-1 cells. NF- $\kappa \mathrm{B}$ suppression was accompanied by ERK, JNK, and MAPK inhibition and consequently COX2 expression decreased. These effects occurred by the sta-

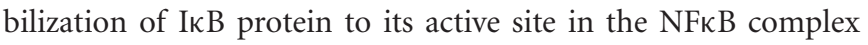
(Zhang et al., 2006; Kang et al., 2008).

Furthermore, procyanidin $\mathrm{B}_{2}$, a polyphenol with potent antiinflammatory effect, inhibited inflammasome activation by the inactivation of the NF- $\mathrm{B}$ signaling pathway, the first stage required for the transcription of inflammasome precursors, through the inhibition of p65 nuclear expression and DNA binding, resulting in the transcriptional repression of target genes, such as $\mathrm{COX}_{2}$, iNOS and production of IL-6 and NO (Martinez-Micaelo et al., 2014).

Ingestion of cocoa polyphenlos interferes in NO metabolism in various spheres. Procyanidins favor NO synthesis and, thereby, inhibit the formation of superoxide and peroxynitrite (Wollgast 
and Anklam, 2000). These phenolic compounds cause arterial vasodilation (Corti et al., 2009), decrease infact size (Yamazaki etal., 2014) and increased walking distance in patients with peripheral artery disease by NO mediated mechanisms (Loffredo et al., 2014). Cocoa diminishes arginase activity in endotelial cells, increases L-arginine levels (a substrate for NO production by eNOS) and increases NO metabolites excretion in urine (Andújar et al., 2012). Ramirez-Sanchez et al. (2010) and MorenoUlloa etal. (2014), have described that epicatechin acts over eNOS by serine 633 and 1177 phosphorylation and threonine 495 dephosphorylation, which in turn, exerts effect on the intracellular pathway of PI3K, enhancing NO formation. Furthermore, epicatechin causes eNOS uncoupling from caveolin1 (cav-1), by intracellular $\mathrm{Ca}^{2+}$ increase, at least, partially mediated by $\mathrm{Ca}^{2+} / \mathrm{CaMKII}$ pathways (Ramirez-Sanchez et al., 2010). $\mathrm{NO}$ is an essential mediator of endothelial function, unless it is excessively produced under oxidative stress conditions, it exerts a predominantly antioxidant and anti-inflammatory function. Although, under pathological conditions, the increased NOS activity may not translate into increased NO production. Reduced NO bioavailability through eNOS "uncoupling" from cav-1 is a contributing factor to reduced local NO in various endothelial dysfunctional injuries, like pulmonary hypertension (Zuckerbraun et al., 2011). All isoforms of NOS utilize $\mathrm{L}$-arginine as the substrate, and molecular oxygen and reduced nicotinamide-adenine-dinucleotide phosphate (NADPH) as cosubstrates. Flavin adenine dinucleotide (FAD), Flavin mononucleotide (FMN), and (6R-)5,6,7,8-tetrahydro-L-biopterin (BH4) are cofactors of all isozymes (Katusic, 2001). Uncoupling occurs under conditions of reduced $\mathrm{BH} 4$ availability where eNOS produces ROS rather than NO. Due to the enhanced oxidative stress seen in many pathological process, an increased degradation of $\mathrm{NO}$ by its reaction with $\mathrm{O} 2-$ - will occur. However, oxidative stress has also been shown to convert eNOS from an NO-producing enzyme to an enzyme that generates $\mathrm{O} 2-$-. Superoxide anions have been recognized as contributing to vascular dysfunction, through mechanisms including endothelial dysfunction, vascular smooth muscle cell growth, lipid peroxidation, and inflammation (Schewe, 2000; Förstermann and Sessa, 2012).

The effects of flavanols, on the thrid trimester of pregnancy, have not yet been fully described. The human placental function depends on NO and PGI biosynthesis. On the third trimester, there is a relative placentary deficiency of BH4 (Kukor et al., 2000). As pregnancy progresses, oxidative stress in the placenta prepares the uterus for labor (Cindrova-Davies et al., 2007). In this period, NO production may lead to greater risk of nitrative damage.

Polyphenol-rich foods consumption have a positive effect in general health, although deleterious effect on the fetus have been reported if ingested by the mother on the third trimester of pregnancy (Luchese et al., 2003; Zielinsky et al., 2010a,b, 2012a,b, 2013; Zielinsky and Busato, 2013; Bubols et al., 2014). The negative effects on the fetus are possibly due to its anti-inflammatory effect on the ductus arteriosus (DA). Fetal circulation has characteristic features, being morphologically and functionally different from extrauterine circulation. The DA plays a fundamental role in directing the blood flow to fetal inferior body parts. Basically, the DA directs $80-85 \%$ of the right ventricular output arising from the superior vena cava, coronary sinus, and a small part from the inferior vena cava to descending aorta. Its histological structure is made up predominantly by a thick muscular layer, differently from the aorta and the pulmonary artery, which increases with gestational age. The fibers have a circumferential orientation, especially at the external layers, facilitating and making effective ductal constriction. These factors may generate lumen alterations which may cause fetal and neonatal complications, such as heart failure, hydrops, neonatal pulmonary hypertension, and even death. Classically, maternal administration of indomethacin and/or other anti-inflammatory drugs interfere in prostaglandins metabolism, causing ductal constriction. In recent years, a growing body of evidence has shown that cocoa, as previously discussed, but also herbs, fruits, nuts, and a wide diversity of substances commonly used in daily diets have definitive effects upon the metabolic pathway of inflammation, with consequent inhibition of prostaglandins synthesis (Zielinsky et al., 2010a). This antiinflammatory action, when polyphenol-rich substances such as cocoa are ingested during the third trimester of pregnancy, may influence the dynamics of fetal DA flow.

Intrauterine constriction of the fetal DA can be a devastating event that may lead to pulmonary hypertension, heart failure or even perinatal death. Maternal ingestion of anti-inflammatory COX inhibitors are the leading cause of DA constriction, although, up to $65 \%$ of cases are considered as of unknown origin (Luchese et al., 2003). We have already shown that after administration of green tea or grape juice to pregnant ewe in the near term the fetuses showed echocardiographic or morphologic characteristics of ductal constriction (Zielinsky et al., 2010a). In another experimental study, the ingestion of green tea as the only source of liquid caused an increase in the flow velocities of the DA, right ventricle hypertrophy and pulmonary hypertension in the echocardiogram of fetal lamb. The histological analysis showed an increase in the avascular media layer, confirming ductal constriction (Zielinsky et al., 2012a). Observational studies in humans also showed that polyphenol rich food ingestion on the third trimester of pregnancy caused ductal contriction (Zielinsky et al., 2010a,b, 2012b; Zielinsky and Busato, 2013) and that the restriction of polyphenols from maternal diet reverted the constrictive effect unto normal flow through the DA even in normal pregnancies (Zielinsky et al., 2012b, 2013). Furthermore, 2 weeks of daily supplementation of polyphenol rich food (total polyphenol of $>3100 \mathrm{mg} /$ day) to pregnant ewe caused ductal constriction and decreased plasmatic lipid peroxidation (TBARS) and increased catalase and glutathione peroxidase levels in maternal plasma when compared to normal diet group (Bubols et al., 2014). Even though there was a significant increase of protein carbonylation and lower nitrite/nitrate ratio, PGE2 level were unaltered in maternal blood samples (Bubols et al., 2014; Table 1). Specifically in relation to maternal cocoa exposition, in an experimental rodent model of ductal constriction, the administration of one dose of $720 \mathrm{mg} / \mathrm{kg}$ of cocoa powder solution through gastric gavage on the last third of pregnancy caused fetal ductal constriction similar to indomethacin $10 \mathrm{mg} / \mathrm{kg}$, but did not alter oxidative stress markers or antioxidant enzymes in the mother or the fetus (submitted).

In short, the ongoing line of investigation relating maternal exposure to polyphenol-rich substances, including cocoa, in late 
Table 1 | Effect of Cocoa, chocolate and polyphenol rich substances and their beneficial effect on the adult or harmful effect on the fetus.

\begin{tabular}{|c|c|c|c|c|}
\hline Reference & Substance & Population & Outcome & Overall Effect \\
\hline Hermann etal. (2006) & $\begin{array}{l}\text { Dark chocolate and } \\
\text { Liquid cocoa }\end{array}$ & Healthy humans & Improved endothelial function. Decreased BP & Beneficial \\
\hline Innes et al. (2003) & Dark chocolate & Healthy humans & Inhibited collagen-induced platelet aggregation & Beneficial \\
\hline Flammer et al. (2012) & Dark chocolate & Humans with heart failure & Increased FMD & Beneficial \\
\hline Loffredo et al. (2014) & Dark chocolate & $\begin{array}{l}\text { Humans with peripheral } \\
\text { arterial disease }\end{array}$ & Increased FMD, MWD and MWT & Beneficial \\
\hline Parsaeyan etal. (2014) & Cocoa powder & Humans with Diabetes & $\begin{array}{l}\text { Lowered blood cholesterol, triglyceride, } \\
\text { LDL-cholesterol, and TNF- } \alpha \text {, hs-CRP, IL-6, by } \\
\text { Bioinformatics and virtual analysis inhibited COX-2 }\end{array}$ & Beneficial \\
\hline Morrison et al. (2014) & Epicatechin & Mice with atherosclerosis & Lowers NFkB and atherosclerotic plaque & Beneficial \\
\hline Zielinsky et al. (2012b) & Polyphenols rich diet & $\begin{array}{l}\text { Pregnant humans with fetal } \\
\text { CDA }\end{array}$ & $\begin{array}{l}\text { Polyphenol restriction from diet caused fetal ductal } \\
\text { dilation }\end{array}$ & Harmful \\
\hline Zielinsky et al. (2007) & $\begin{array}{l}\text { Green tea, mate tea, } \\
\text { grape juice }\end{array}$ & Pregnant ewe & Fetal ductus arteriosus constriction & Harmful \\
\hline Zielinsky et al. (2012a) & Green tea & Pregnant ewe & Fetal ductus arteriosus constriction & Harmful \\
\hline Bubols et al. (2014) & Polyphenols rich diet & Pregnant ewe & $\begin{array}{l}\text { Fetal ductus arteriosus constriction, lowers oxidative } \\
\text { stress markers }\end{array}$ & Harmful \\
\hline
\end{tabular}

BP, blood pressure; DAC, ductus arteriosus constriction; FMD, flow mediated dilatation; COX, cyclooxygenase; MWD, mean walking distance; MWT, mean walking time; CDA, constriction of ductus arteriosus.

pregnancy, points toward the perspective of deleterious effects to the fetus, mainly fetal DA constriction, which carries a high risk of neonatal pulmonary hypertension and its potential severe consequences. Additional studies are necessary to establish dose ranges and serum concentrations necessary to determine safety and well being in the human setting.

\section{ACKNOWLEDGMENTS}

The authors have been supported in part by grants of CAPES Foundation, Brazil, CNPq (National Council of Scientific and Technological Development), Brazil, and FAPERGS (Research Support Foundation, Rio Grande do Sul, Brazil).

The participation of the following collaborators in several steps of this line of investigation is acknowledged: Alexandra Cardoso, Alexandre Bestetti, Alexandre Naujorks, Ana Zilio, André Busato, Andressa Oliveira, Angela Arnt, Antonio Piccoli, Augusto Shimanoe, Bruna Cunha, Camila Brum, Camila Ritter, Camila Weschenfelder, Carolina Barbisan, Caroline Klein, Cristine Weihrauch, Daniel Mattos, Débora Alves, Elizandra Trombini, Fabiana Jaeger, Fernanda Lin, Fernanda Swarowski, Gabriela Lorentz, Gabriela Pozzobon, Guilherme Bubols, Honório Menezes, João Luiz Manica, Julia Silva, Kenya Lampert, Letícia Almeida, Lucas Aita, Luciano Bender, Luiz Henrique Nicoloso, Marcelo Alievi, Marcelo Pizzato, Marina Moraes, Marinez Barra, Mauro Lopes, Melânia Lacerda, Melissa Markoski, Natássia Sulis,
Patrícia Pizzato, Pedro Rafael Magno, Renato Frajndlich, and Solange Garcia.

The authors also thank the Federal University of Santa Maria, Rio Grande do Sul, Santa Maria, Brazil, and the Federal University of Rio Grande do Sul, Porto Alegre, Brazil,for the technical support during the experimental studies.

\section{REFERENCES}

Andújar, I., Recio, M. C., Giner, R. M., and Ríos, J. L. (2012). Cocoa polyphenols and their potential benefits for human health. Oxid. Med. Cell. Longev. 2012:906252. doi: 10.1155/2012/906252

Arranz, S., Valderas-Martinez, P., Chiva-Blanch, G., Casas, R., Urpi-Sarda, M., Lamuela-Raventos, R. M., et al. (2013). Cardioprotective effects of cocoa: clinical evidence from randomized clinical intervention trials in humans. Mol. Nutr. Food Res. 57, 936-47. doi: 10.1002/mnfr.201200595

Arts, I. C., Hollman, P. C., and Kromhout, D. (1999). Chocolate as a source of tea flavonoids. Lancet 354:488. doi: 10.1016/S0140-6736(99)02267-9

Bubols, G. B., Zielinsky, P., Piccoli, A. L. Jr., Nicoloso, L. H., Vian, I., Moro, A. M., et al. (2014). Nitric oxide and reactive species are modulated in the polyphenolinduced ductus arteriosus constriction in pregnant sheep. Prenat. Diagn. doi: 10.1002/pd.4463. [Epub ahead of print].

Cindrova-Davies, T., Yung, H. W., Johns, J., Spasic-Boskovic, O., Korolchuk, S., Jauniaux, E., et al. (2007). Oxidative stress, gene expression, and protein changes induced in the human placenta during labor. Am. J. Pathol. 171, 1168-1179. doi: 10.2353/ajpath.2007.070528

Corti, R., Flammer, A. J., Hollenberg, N. K., and Luscher, T. F. (2009). Cocoa and cardiovascular health. Circulation 119, 1433-1441. doi: 10.1161/CIRCULATIONAHA.108.827022 
Flammer, A. J., Sudano, I., Wolfrum, M., Thomas, R., Enseleit, F., Périat, D., et al. (2012). Cardiovascular effects of flavanol-rich chocolate in patients with heart failure. Eur. Heart J. 33, 2172-2180. doi: 10.1093/eurheartj/ehr448

Förstermann, U., and Sessa, W. C. (2012). Nitric oxide synthases: regulation and function. Eur. Heart J. 33, 829-837, 837a-837d. doi: 10.1093/eurheartj/ehr304

Heptinstall, S., May, J., Fox, S., Kwik-Uribe, C., and Zhao, L. (2006). Cocoa flavanols and platelet and leukocyte function: recent in vitro and ex vivo studies in healthy adults. J. Cardiovasc. Pharmacol. 47(Suppl. 2), S197-S205; discussion S206-S209.

Hermann, F., Spieker, L. E., Ruschitzka, F., Sudano, I., Hermann, M., Binggeli, C., et al., (2006). Dark chocolate improves endothelial and platelet function. Heart 92, 119-120. doi: 10.1136/hrt.2005.063362

Hsu, T. C., Young, M. R., Cmarik, J., and Colburn, N. H. (2000). Activator protein 1 (AP-1)- and nuclear factor kappaB (NF-kappaB)-dependent transcriptional events in carcinogenesis. Free Radic. Biol. Med. 28, 1338-1348. doi: 10.1016/S0891-5849(00)00220-3

Innes, A. J., Kennedy, G., McLaren, M., and Bancroft, A. J. (2003). Dark chocolate inhibits platelet aggregation in healthy volunteers. Platelets 14, 325-327. doi: 10.1080/0953710031000123681

Kang, N. J., Lee, K. W., Lee, D. E., Rogozin, E. A., Bode, A. M., Lee H. J., et al. (2008). Cocoa procyanidins suppress transformation by inhibiting mitogen-activated protein kinase kinase. J. Biol. Chem. 283, 20664-20673. doi: 10.1074/jbc.M800263200

Katusic, Z. S. (2001). Vascular endothelial dysfunction: does tetrahydrobiopterin play a role? Am. J. Physiol. Heart Circ. Physiol. 281, H981-H986.

Kukor, Z., Valent, S., and Tóth, M. (2000). Regulation of nitric oxide synthase activity by tetrahydrobiopterin in human placentae from normal and pre-eclamptic pregnancies. Placenta 21, 763-772. doi: 10.1053/plac.2000.0584

Lee, K. W., Kundu, J. K., Kim, O., Chun, K., and Lee, J. (2006). Biochemical, molecular, and genetic mechanisms cocoa polyphenols inhibit phorbol esterinduced superoxide anion formation in cultured HL-60 cells and expression of cyclooxygenase-2 and Activation of NF- $\kappa \mathrm{B}$ and MAPKs in mouse skin in vivo. J. Nutr. 136, 1150-1155.

Lee, K. W., and Lee, H. J. (2006). The roles of polyphenols in cancer chemoprevention. Biofactors 26, 105-121.

Loffredo, L., Perri, L., Catasca, E., Pignatelli, P., Brancorsini, M., Nocella, C., etal. (2014). Dark chocolate acutely improves walking autonomy in patients with peripheral artery disease. J. Am. Heart Assoc. 3:e001072. doi: 10.1161/JAHA.114.001072

Luchese, S., Mânica, J. L., and Zielinsky, P. (2003). Intrauterine ductus arteriosus constriction: analysis of a historic cohort of 20 cases. Arq. Bras. Cardiol. 81, 405-410, 399-404.

Martinez-Micaelo, N., González-Abuín, N., Pinent, M., Ardévol, A., and Blay, M. (2014). Procyanidin $B_{2}$ inhibits inflammasome-mediated IL- $1 \beta$ production in lipopolysaccharide-stimulated macrophages. Mol. Nutr. Food Res. doi: 10.1002/mnfr.201400370

Moreno-Ulloa, A., Romero-Perez, D., Villarreal, F., Ceballos, G., and RamirezSanchez, I. (2014). Cell membrane mediated (-)-epicatechin effects on upstream endothelial cell signaling: evidence for a surface receptor. Bioorg. Med. Chem. Lett. 24, 2749-2752. doi: 10.1016/j.bmcl.2014.04.038

Morrison, M., van der Heijden, R., Heeringa, P., Kaijzel, E., Verschuren, L., Blomhoff, R., et al. (2014). Epicatechin attenuates atherosclerosis and exerts anti-inflammatory effects on diet-induced human-CRP and NFKB in vivo. Atherosclerosis 233, 149-156. doi: 10.1016/j.atherosclerosis.2013.12.027

Parsaeyan, N., Mozaffari-Khosravi, H., Absalan, A., and Mozayan, M. R. (2014). Beneficial effects of cocoa on lipid peroxidation and inflammatory markers in type 2 diabetic patients and investigation of probable interactions of cocoa active ingredients with prostaglandin synthase-2 (PTGS-2/COX-2) using virtual analysis. J. Diabetes and Metab. Disord. 13:30 doi: 10.1186/2251-6581-13-30

Ramirez-Sanchez, I., Maya, L., Ceballos, G., and Villarreal, F. (2010). (-)-epicatechin activation of endothelial cell endothelial nitric oxide synthase, nitric oxide, and related signaling pathways. Hypertension 55, 1398-1405. doi: 10.1161/HYPERTENSIONAHA.109.147892

Romier-Crouzet, B., Van De Walle, J., During, A., Joly, A., Rousseau, C., Henry, O., et al. (2009). Inhibition of inflammatory mediators by polyphenolic plant extracts in human intestinal Caco-2 cells. Food Chem. Toxicol. 47, 1221-1330. doi: 10.1016/j.fct.2009.02.015
Schewe, T. (2000). 15-lipoxygenase-1: a prooxidant enzyme. Biol. Chem. 383, 365-374.

Selmi, C., Mao, T. K., Keen, C. L., Schmitz, H. H., and Eric Gershwin, M. (2006). The anti-inflammatory properties of cocoa flavanols. J. Cardiovasc. Pharmacol. 47(Suppl. 2), S163-S171; discussion S172-S176.

Sies, H., Schewe, T., Heiss, C., and Kelm, M. (2005). Cocoa polyphenols and inflammatory mediators. Am. J. Clin. Nutr. 81, 304S-312S.

Wollgast, J., and Anklam, E. (2000). Polyphenols in chocolate: is there a contribution to human health? Food Res. Int. 33, 449-459. doi: 10.1016/S0963-9969(00) 00069-7

Yamazaki, K. G., Andreyev, A. Y., Ortiz-Vilchis, P., Petrosyan, S., Divakaruni, A. S., Wiley, S. E., et al. (2014). Intravenous (-)-epicatechin reduces myocardial ischemic injury by protecting mitochondrial function. Int. J. Cardiol. 175, 297-306. doi: 10.1016/j.ijcard.2014.05.009

Zhang, W. Y., Liu, H. Q., Xie, K. Q., Yin, L. L., Li, Y., Kwik-Uribe, C. L., et al. (2006). Procyanidin dimer B2 [epicatechin-(4beta-8)-epicatechin] suppresses the expression of cyclooxygenase-2 in endotoxin-treated monocytic cells. Biochem. Biophys. Res. Commun. 345, 508-515. doi: 10.1016/j.bbrc.2006.04.085

Zielinsky, P., and Busato, S. (2013). Prenatal effects of maternal consumption of polyphenol-rich foods in late pregnancy upon fetal ductus arteriosus. Birth Defects Res. Part C Embryo Today Rev. 99, 256-274. doi: 10.1002/bdrc.21051

Zielinsky, P., Manica, J. L., Piccoli, A. L. Jr., Areias, J. C. N., Nicoloso, L. H., Menezes, H. S., et al. (2007). Experimental study of the role of maternal consumption of green tea, mate tea and grape juice on fetal ductal constriction. Ultrasound Obstet. Gynecol. 30:515. doi: 10.1002/uog.4591

Zielinsky, P., Manica, J. L., Piccoli, A. L. Jr., Nicoloso, L. H., Barra, M., Alievi, M. M., et al. (2012a). Fetal ductal constriction caused by maternal ingestion of green tea in late pregnancy: an experimental study. Prenat. Diagn. 32, 921-926. doi: $10.1002 / \mathrm{pd} .3933$

Zielinsky, P., Piccoli, A. L. Jr., Manica, J. L., Nicoloso, L. H., Vian, I., Bender, L., et al. (2012b). Reversal of fetal ductal constriction after maternal restriction of polyphenol-rich foods: an open clinical trial. J. Perinatol. 32, 574-579. doi: 10.1038/jp.2011.153

Zielinsky, P., Piccoli, A. L., Manica, J. L. L., and Nicoloso, L. H. S. (2010a). New insights on fetal ductal constriction: role of maternal ingestion of polyphenol-rich foods. Expert Rev. Cardiovasc. Ther. 8, 291-298. doi: 10.1586/erc.09.174

Zielinsky, P., Piccoli, A. L. Jr., Manica, J. L., Nicoloso, L. H., Menezes, H., Busato, A., et al. (2010b). Maternal consumption of polyphenol-rich foods in late pregnancy and fetal ductus arteriosus flow dynamics. J. Perinatol. 30, 17-21. doi: 10.1038/jp.2009.101

Zielinsky, P., Piccoli, A. L. Jr., Vian, I., Zílio, A. M., Naujorks, A. A., Nicoloso, L. H., et al. (2013). Maternal restriction of polyphenols and fetal ductal dynamics in normal pregnancy: an open clinical trial. Arq. Bras. Cardiol. 101, 217-225. doi: $10.5935 /$ abc. 20130166

Zuckerbraun, B. S., George, P., and Gladwin, M. T. (2011). Nitrite in pulmonary arterial hypertension: therapeutic avenues in the setting of dysregulated arginine/nitric oxide synthase signalling. Cardiovasc. Res. 89, 542-552. doi: $10.1093 / \mathrm{cvr} / \mathrm{cvq} 370$

Conflict of Interest Statement: The authors declare that the research was conducted in the absence of any commercial or financial relationships that could be construed as a potential conflict of interest.

Received: 21 October 2014; paper pending published: 08 November 2014; accepted: 02 December 2014; published online: 22 December 2014.

Citation: Zielinsky P, Martignoni FV and Vian I (2014) Deleterious effects of maternal ingestion of cocoa upon fetal ductus arteriosus in late pregnancy. Front. Pharmacol. 5:281. doi: 10.3389/fphar.2014.00281

This article was submitted to Experimental Pharmacology and Drug Discovery, a section of the journal Frontiers in Pharmacology.

Copyright (c) 2014 Zielinsky, Martignoni and Vian. This is an open-access article distributed under the terms of the Creative Commons Attribution License (CC BY). The use, distribution or reproduction in other forums is permitted, provided the original author(s) or licensor are credited and that the original publication in this journal is cited, in accordance with accepted academic practice. No use, distribution or reproduction is permitted which does not comply with these terms. 